\title{
MOLECULAR CHARACTERIZATION AND SEQUENCE PHYLOGENETIC ANALYSIS OF SURFACE ANTIGEN 3 (SAG3) GENE OF LOCAL INDIAN ISOLATES (CHENNAI AND IZATNAGAR) OF Toxoplasma gondii
}

\author{
Vikrant SUDAN(1), Anup Kumar TEWARI(2) \& Harkirat SINGH(3)
}

\begin{abstract}
SUMMARY
Context and objective: The molecular characterization of local isolates of Toxoplasma gondii is considered significant so as to assess the homologous variations between the different loci of various strains of parasites. Design and setting: The present communication deals with the molecular cloning and sequence analysis of the 1158 bp entire open reading frame (ORF) of surface antigen 3 (SAG3) of two Indian T. gondii isolates (Chennai and Izatnagar) being maintained as cryostock at the IVRI. Method: The surface antigen 3 (SAG3) of two local Indian isolates were cloned and sequenced before being compared with the available published sequences. Results: The sequence comparison analysis revealed $99.9 \%$ homology with the standard published RH strain sequence of T. gondii. The strains were also compared with other established published sequences and found to be most related to the P-Br strain and CEP strain (both $99.3 \%$ ), and least with PRU strain (98.4\%). However, the two Indian isolates had 100\% homology between them. Conclusion: Finally, it was concluded that the Indian isolates were closer to the RH strain than to the P-Br strain (Brazilian strain), the CEP strain and the PRU strains (USA), with respect to nucleotide homology. The two Indian isolates used in the present study are known to vary between themselves, as far as homologies related to other genes are concerned, but they were found to be $100 \%$ homologous as far as SAG3 locus is concerned. This could be attributed to the fact that this SAG3 might be a conserved locus and thereby, further detailed studies are thereby warranted to exploit the use of this particular molecule in diagnostics and immunoprophylactics. The findings are important from the point of view of molecular phylogeny.
\end{abstract}

KEYWORDS: Indian isolates; Molecular characterization; SAG3; Toxoplasma gondii.

\section{INTRODUCTION}

Toxoplasma gondii, an obligate intracellular coccidian parasite, has acquired utmost zoonotic relevance in the current scenario around the globe, accounting for abortions, stillbirths, and neonatal complications in livestock, especially in sheep, goats and pigs ${ }^{9,16,30}$. The condition leads to life-threatening consequences both in immunocompromised human patients suffering from acquired immune deficiency syndrome (AIDS) and those with organ transplants ${ }^{2}$. In India, the condition has exhibited itself as acquired ocular toxoplasmosis ${ }^{4}$, in immunocompetent patients, bringing about possible similarities with South American strains which are known to exhibit a high rate of ocular involvement ${ }^{20}$. A third of the world's total population is thought to be at risk of infection ${ }^{22}$. Of late, different strains of Toxoplasma gondii are known to induce different cytokine responses ${ }^{5}$ and thereby vary in their pathogenesis. The surface antigens of $T$. gondii are the major targets as key molecules for immunodiagnosis as well as immunoprophylaxis because of their initial presentation to the host immune system. Surface antigen 3 (SAG3), an under-reported $43 \mathrm{kDa}$ glycoaminoglycan-binding protein associated with binding of host heparin sulfate proteoglycans (HSPGs) ${ }^{18}$, shares primary structure similarity with another proven Surface antigen 1 (SAG1) ${ }^{7}$ protein. It was considered interesting to carry out the primer-directed amplification of the open reading frame (ORF) of surface antigen 3 (SAG3) gene of Indian isolates of T. gondii viz. Chennei (CHEN) and Izatnagar (IZN) isolates, maintaining them at the IVRI and cloning them in a heterologous prokaryotic system. Moreover, the two Indian isolates used in the present study are known to vary between themselves as far as homologies related to other gene loci like GRA $5^{26}$, MIC $3^{23}$ and SAG $2^{27}$ are concerned, but there is no literature available as far as SAG3 homologies are concerned. In the present study, the cloned genes were custom sequenced and the information was compared with the available sequences of the same gene in the GenBank in order to establish the phylogenetic identity of the SAG3 gene among the various isolates.

\section{METHODS}

Propagation of $\boldsymbol{T}$. gondii tachyzoites: Inbred Swiss albino adult mice, maintained on standard feed (pellets) and water ad libitum, were

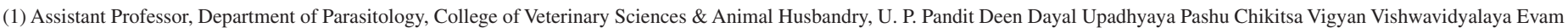
Go Anusandhan Sansthan (DUVASU), Mathura - 281001, India.

(2) Principal Scientist, Division of Parasitology, IVRI, Izatnagar, India.

(3) Assistant Professor, Department of Parasitology, GADVASU, Ludhiana, India.

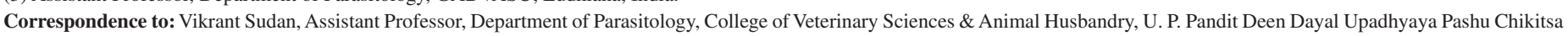

Vigyan Vishwavidyalaya Evam Go Anusandhan Sansthan (DUVASU), Mathura - 281001, India; Email: viks.sudan@ gmail.com 


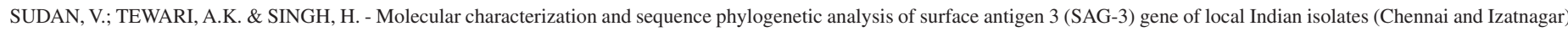
of Toxoplasma gondii. Rev. Inst. Med. Trop. Sao Paulo, 57(3): 205-9, 2015.

intraperitoneally infected with 100 mouse-adapted Chennei and Izatnagar T. gondii tachyzoite isolates that were cryopreserved and maintained at a divisional laboratory, IVRI. These two Indian isolates were originally isolated from the tested-positive blood, heart and brain tissues of freerange chickens (Gallus domesticus) naturally infected by $T$. gondii ${ }^{25}$ and isolated after Cat inoculation assays. The infected mice were monitored daily for the development of signs of infection. Infected mice exhibiting peritonitis were euthanized and peritoneal lavage was aspirated following inoculation of $5 \mathrm{~mL}$ of sterile phosphate buffered saline (PBS, $\mathrm{pH}$ 7.2) in the peritoneal cavity with due care in avoiding injury to visceral organs. The contents were washed thrice with PBS ( $\mathrm{pH} 7.2)$ and the live tachyzoites were counted.

Separation of host cell-free tachyzoites: The host cell-free tachyzoites were separated using standard protocol ${ }^{15}$. Briefly, the peritoneal fluid containing free tachyzoites and tachyzoite infected macrophages was collected in PBS $(\mathrm{pH} \mathrm{7.4)}$ and washed thrice in PBS (pH 7.4) while repeatedly centrifuging at $5000 \mathrm{rpm}$ for $10 \mathrm{~min}$. Following this, a final pellet was re-suspended in $5 \mathrm{~mL}$ of PBS $(\mathrm{pH}$ 7.4). The intracellular tachyzoites were separated and made free from the macrophages by passing the contents repeatedly through a $27 \mathrm{~g}$ needle fitted in a $10 \mathrm{~mL}$ sterile syringe. The host cell-free tachyzoite suspension was washed with $20 \mathrm{~mL}$ of PBS ( $\mathrm{pH} 7.4$ ), debris was allowed to settle down in the centrifuge tube for $10 \mathrm{~min}$ and the supernatant was collected and, following this, passed through a pre-wetted (with PBS $\mathrm{pH} 7.4$ ) polycarbonate membrane filter of $3 \mu \mathrm{m}$ pore size slowly (at the rate of one $\mathrm{mL}$ per 2-3 $\mathrm{min}$ ). The filtrate was centrifuged (3000 rpm for $10 \mathrm{~min}$ ) and the tachyzoites in sediment were re-suspended in one $\mathrm{mL}$ of PBS ( $\mathrm{pH} 7.4)$

Isolation of total RNA of $\boldsymbol{T}$. gondii: Total RNA was extracted directly from the purified tachyzoites using Trizol $^{\circledR}$ reagent (Gibco BRL) while following the manufacturer's protocol. Briefly, one $\mathrm{mL}$ of Trizol was added to the suspension containing $5-10 \times 10^{6}$ tachyzoites, repeatedly pipetted to kill the tachyzoites and following this, incubated at $30^{\circ} \mathrm{C}$ for five min to dissociate nucleoprotein complexes. The suspension was vigorously shaken for $15 \mathrm{sec}$ after adding $0.2 \mathrm{~mL}$ of chloroform and then centrifuged at $12,000 \mathrm{~g}$ for $15 \mathrm{~min}$ at $4{ }^{\circ} \mathrm{C}$. This facilitates the separation into lower organic phase and upper aqueous phase. The aqueous phase was transferred to a fresh tube, $0.5 \mathrm{~mL}$ of the isopropyl alcohol was poured into the tube and the RNA was allowed to precipitate while keeping the tube at $15-30{ }^{\circ} \mathrm{C}$ for $10 \mathrm{~min}$. The tube was centrifuged at $12,000 \mathrm{~g}$ for $10 \mathrm{~min}$ at $4{ }^{\circ} \mathrm{C}$. The RNA pellet was washed once with one $\mathrm{mL}$ of $75 \%$ ethanol prepared using $0.01 \%$ of diethylpyrocarbonate (DEPC) treated water. The sample was mixed by vortexing and centrifuged at 7,500 x g for five min at $4{ }^{\circ} \mathrm{C}$. The RNA pellet was air-dried, reconstituted in 100 $\mu \mathrm{L}$ of RNA storage buffer (Ambion) and stored at $-20{ }^{\circ} \mathrm{C}$ until further use. Purity and concentration of total RNA was checked by ethidium bromide stained agarose gel electrophoresis, performed at 2-3 volts $/ \mathrm{cm}^{2}$.

Synthesis of complimentary DNA (cDNA) by reverse transcription: cDNA was synthesized from the total RNA isolated from the $T$. gondii tachyzoites of both the isolates, using oligo dT primer while following the standard protocol ${ }^{23}$. The cDNA, thus synthesized, was quantified using a spectrophotometer (Nanodrop ${ }^{\circledR}$, USA).

Polymerase chain reaction-based (PCR) amplification of the SAG3 gene of Indian isolates: The entire open reading frame (ORF) of the SAG3 gene of $T$. gondii (CHN and IZN isolates) was PCR amplified using a pair of specific primers as described by SUDAN et al. $2012^{28}$ (forward primer (TS3F) 5'-ATGCAGCTGTGGCGGCGCAG-3' and reverse (TS3R) 5'-TTAGGCAGCCACATGCACAAG-3'). The PCR reactions were carried out in a standard $25 \mu \mathrm{L}$ reaction volume with initial denaturation of DNA strands at $95^{\circ} \mathrm{C}$ for five min followed by 32 cycles of denaturation at $95^{\circ} \mathrm{C}$ for $50 \mathrm{sec}$, primer annealing at $62^{\circ} \mathrm{C}$ for $75 \mathrm{sec}$ and strand elongation at $72{ }^{\circ} \mathrm{C}$ for $50 \mathrm{sec}$. Thereafter one cycle of final extension of the strands was carried out at $72{ }^{\circ} \mathrm{C}$ for $12 \mathrm{~min}$. The PCR amplifications were confirmed by visualization of the product on $1.5 \%$ agarose gel stained with ethidium bromide following electrophoresis.

Molecular cloning and characterization of the SAG3 gene of Indian isolates: The amplified ORF of the SAG3 genes of Indian isolates of T. gondii were purified using a Qiagen Mini elute gel extraction kit (Qiagen GmbH, Hilden, Germany) in accordance with the manufacturer's protocol. Following this, competent Escherichia coli DH5 cells were prepared following the standard calcium chloride treatment method ${ }^{23}$. Ligation reaction for the cloning of SAG3 (amplified from T. gondii Indian isolates) into InsTAclone PCR cloning vector (Qiagen, Germany) as well as transformation of DH5 cells was carried out as per the company's protocol. The positive clones were identified by blue-white colony screening method. Further confirmation was carried out by restriction analysis of the plasmid DNA isolated from the white colonies with PstI and EcoRI as well as by colony PCR following standard protocol ${ }^{24}$. The restriction digestion reaction was carried out at $37{ }^{\circ} \mathrm{C}$ for four $\mathrm{h}$. The digested product as well, as the colony PCR amplified products, was visualized in the ethidium bromide-stained agarose gel following electrophoresis. The subcultures of a positive clone harboring the desired SAG3 genes of both the Indian isolates were custom DNA sequenced from the Department of Biochemistry, Delhi University.

Data analysis: The sequence information received was analyzed using DNASTAR and GeneTool software. The sequences, hence received sequence submitted to GenBank (Accession No.: HQ291783 \& HQ291784 for Chennei and Izatnagar isolates, respectively). Moreover, these two sequences were compared with an earlier sequenced RH strain sequence (Accession No.: FJ825705) from the department along with other published sequences viz., CEP (Accession No.: AF340229); P-Br (Accession No.: AY187280) and PRU (Accession No.: AF340228) from across the world through the GenBank using online Nucleotide BLAST Softwares (http://blast.ncbi.nlm.nih.gov/).

\section{RESULTS}

Viability of cryopreserved T. gondii: All the infected mice started showing characteristic signs of the disease from Day-7 Post Infection (PI). The clinical signs included raised \& rough fur coat, pendulous abdomen, severe ascites, dullness, tachypnoea marked by resting on either the walls of the cages, on the nozzle of water bottle or on other resting mice with their forelegs. Microscopically, a large number of tachyzoites were detectable (either free or within the peritoneal macrophages suspended in the aspirated peritoneal fluid).

PCR amplification, molecular cloning and molecular characterization of the SAG3 gene of Indian isolates: The whole ORF of the SAG3 gene was amplified from the cDNA of Indian isolates of T. gondii using the specific forward and reverse primers. The amplicons 


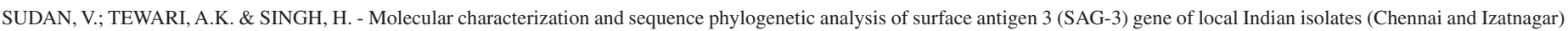
of Toxoplasma gondii. Rev. Inst. Med. Trop. Sao Paulo, 57(3): 205-9, 2015.

were resolved as a single band of $1158 \mathrm{bp}$ (Fig. 1). It was further purified for ligation in InsTAclone PCR cloning vector. The selection of positive colonies was performed by colony PCR using the specific primers and also by restriction enzyme digestion of the recombinant plasmids with PstI and EcoRI for the release of insert. The results of restriction enzyme digestion (Fig. 2) as well as colony PCR (Fig. 3) were checked by agarose gel electrophoresis.

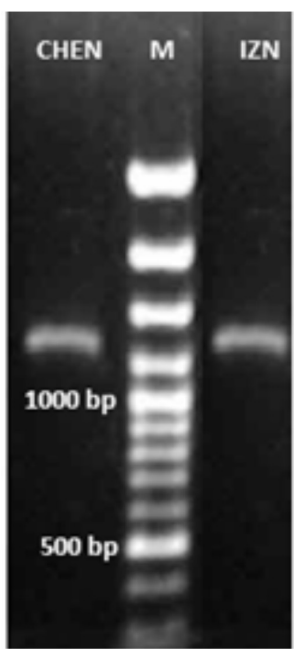

Fig. 1 - Specific PCR amplification of ORF of SAG3 gene of Indian isolates of T. gondii on $1.5 \%$ agarose gel. Lane CHEN: Amplicon of 1158 bp from T. gondii Chennai isolate; Lane M: Marker 100 bp DNA ladder plus; Lane IZN: Amplicon of 1158 bp from T. gondii Izatnagar isolate.

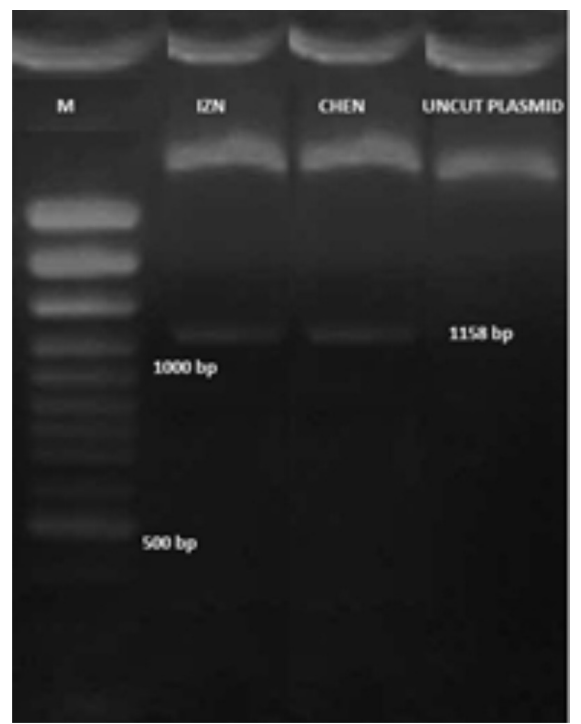

Fig. 2 - Release of SAG3 insert by restriction digestion of insTA cloning vector of the two Indian isolates on $1.5 \%$ agarose gel. Lane M: Marker 100 bp DNA ladder plus (MBI Fermentas); Lane IZN: Insert release after PstI and EcoRI digestion of vector containing Izatnagar isolate; Lane CHEN: Insert release after PstI and EcoRI digestion of vector containing Chennai isolate; Lane Uncut Plasmid: Undigested recombinant insTA cloning vector.

Data analysis: The nucleotide sequence revealed $99.9 \%$ (Fig.4) sequence homology of SAG3 ORF between the Indian isolates with

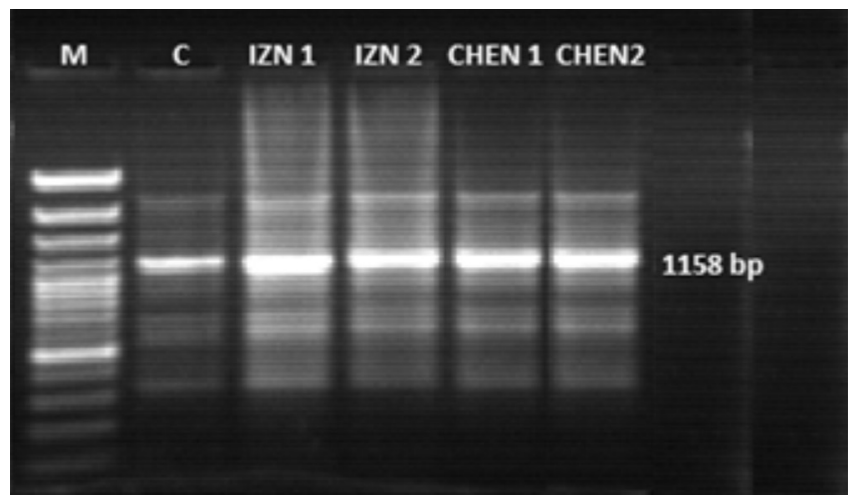

Fig. 3 - Colony PCR confirming the amplifications of 1158 bp specific SAG3 amplicons of Indian isolates on 1.5\% agarose gel. Lane M: Marker 100 bp DNA ladder plus; Lane C: Positive control DNA of T. gondii; Lane IZN 1,2: Amplicon of $1158 \mathrm{bp}$ from T. gondii Izatnagar isolate; Lane CHEN 1,2: Amplicon of $1158 \mathrm{bp}$ from $T$. gondii Chennai isolate.

that of the earlier sequenced RH strain sequence. A comparison of the nucleotide sequence of T. gondii Indian isolates revealed 100\% homology between the Chennei and the Izatnagar isolates. Furthermore, there is a 99.3\% identity with P-Br and the CEP SAG3 sequence and $98.4 \%$ with PRU. A phylogenetic association, for analyzing the identity between strains and testing the robustness of the association, was done using the online bootstrap method (http://blast.ncbi.nlm.nih.gov/) to delineate its relationship with other referral stains (Fig. 5).

\begin{tabular}{|c|c|c|c|c|c|c|c|c|}
\hline \multicolumn{9}{|c|}{ Percent Identity } \\
\hline \multirow{8}{*}{$\begin{array}{l}\frac{1}{2} \\
\frac{2}{3} \\
4 \\
\frac{5}{6}\end{array}$} & 1 & 2 & 3 & 4 & 5 & 6 & & \multirow{8}{*}{$\begin{array}{l}\text { RH strain } \\
\text { CEP } \\
\text { Chennai } \\
\text { Izatnagar } \\
\text { PBR } \\
\text { PRU }\end{array}$} \\
\hline & & 99.4 & 99.9 & 99.9 & 99.4 & 97.7 & 1 & \\
\hline & 0.6 & & 99.3 & 99.3 & 98.8 & 97.6 & 2 & \\
\hline & 0.1 & 0.7 & & 100.0 & 99.3 & 97.6 & 3 & \\
\hline & 0.1 & 0.7 & 0.0 & & 99.3 & 97.6 & 4 & \\
\hline & 0.9 & 1.5 & 1.0 & 1.0 & & 97.0 & 5 & \\
\hline & 2.4 & 2.5 & 2.5 & 2.5 & 3.3 & & 6 & \\
\hline & 1 & 2 & 3 & 4 & 5 & 6 & & \\
\hline
\end{tabular}

Fig. 4 - Sequence pair distances of SAG3 Clustal V (weighted).

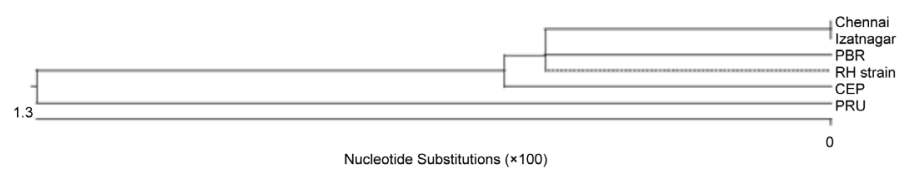

Fig. 5 - Phylogenetic tree of nucleotide sequence of SAG3 Clustal V (weighted).

The Adenine and Thymine (A+T) content of the SAG3 gene of both the Indian isolates was found to be $42.57 \%$, whereas the Guanine and Cytosine $(\mathrm{G}+\mathrm{C})$ content was $57.43 \%$. The nucleotide homology was found to be $99.9 \%$ with the earlier sequenced $\mathrm{RH}$ strain. There was a substitution of a single nucleotide of A instead of $\mathrm{G}$ at the $397^{\text {th }}$ position of the SAG3 nucleotide sequence of both the Indian isolates. The nucleotide substitution resulted in the change of a single nucleotide residue in the deduced amino acid sequence at the $133^{\text {rd }}$ position as asparagine $(\mathrm{N})$ instead of aspartic acid (D). As a whole, Indian isolates were closer to the RH strain than to the P-Br strain (Brazilian strain) and CEP strain and PRU strains (USA), with respect to the nucleotide homology. 


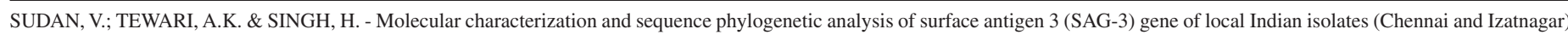
of Toxoplasma gondii. Rev. Inst. Med. Trop. Sao Paulo, 57(3): 205-9, 2015.

\section{DISCUSSION}

The significance of toxoplasmosis has increased particularly in immune compromised and/or HIV/AIDS patients, with an alarming prevalence in developing countries such as India. The presence of brain cysts is often associated with various psychiatric disorders and behavioral alterations ${ }^{29}$ such as schizophrenia ${ }^{8,32}$ alongside other brain pathologies and ocular involvement ${ }^{25}$ in both immunocompromised and immunocompetent individuals ${ }^{1,11}$. In order to precisely define the magnitude of the disease, it was of interest to investigate the genetic diversity of the pathogen among the $T$. gondii strains using advanced biotechnological approaches.

Surface antigen 3 (SAG3), a $43 \mathrm{kDa}$ glycoprotein, is a glycosylphosphatidylinisotol-anchored (GPI) membrane-bound protein in the developmental stages of the pathogen (tachyzoites \& bradyzoites) parasite ${ }^{6,19}$. The protein was earlier identified as $\mathrm{P}_{43}$. It was cloned and sequenced for the first time by CESBRON-DELAUW et al. in $1994^{7}$ followed by FUX et al. in $2003^{13}$. SAG3 has primary structure similarity with Surface antigen 1 (SAG1) ${ }^{7}$. SAG3 is a glycoaminoglycan-binding protein associated with binding of host heparin sulfate proteoglycans (HSPGs) ${ }^{18}$. The SAG3-HSPGs interaction facilitates the parasite's attachment to target cells. Furthermore, it has been shown that targeted disruption of the GPI-anchored surface antigen SAG3 gene in T. gondii resulted in decreased host cell adhesion and virulence of the parasite for mice $^{10}$. In immunoprophylactic application, rSAG3 conferred partial protection in mice, which was mediated through Th1 type immune response $^{21}$. However, molecular characterization of the SAG3 gene of $T$. gondii of Indian isolates has not been attempted so far. The present study reports the molecular characterization of the surface antigen 3 (SAG3) gene of $T$. gondii of Indian isolates and ascertains its molecular homology with some other strains of the same parasites that are prevalent across the globe.

Worldwide, only one valid species of Toxoplasma exists. However, based on molecular genotyping studies, varied fundamental clonal population isolates of $T$. gondii have been recognized. The molecular diversity in the distinct and/or related Toxoplasma stabilates is routinely evaluated by sequence-based analysis among the different isolates. Recently, different strains of Toxoplasma gondii have been known to induce varying levels of cytokine responses ${ }^{5}$ and thereby vary in their pathogenesis, hence the study of the phylogeny has gained ultra importance owing to the variation in pathogenesis at the strain levels. Moreover, the two Indian isolates used in the present study are known to vary between themselves as far as homologies related to other gene loci like GRA $5^{26}$, MIC $3^{23}$ and SAG $2^{27}$ are concerned but they were found to be $100 \%$ homologous as far as SAG3 locus is concerned. This could be attributed to the fact that this SAG3 might be a conserved locus and thereby, further detailed studies are thereby warranted to exploit the use of this particular molecule in diagnostics and immunoprophylactics.

Interestingly, differences at the lineages sequence level of DNA among the predominant clones are less than $2 \%^{14}$. Transmission of the parasite through carnivorism and scavenging among intermediate hosts, bypassing sexual recombination events in the definitive host, i.e. cats ${ }^{17,30}$, parthenogenetic formation of oocysts by many unfertilized macrogametes of the parasite in the small intestine of cats ${ }^{12}$, and simultaneous infection with different strains of $T$. gondii are some plausible reasons that can explain the existence of the clonal population structure in T. gondii ${ }^{3}$.

\section{CONCLUSION}

In the present study, the SAG3 gene of T.gondii was cloned, sequenced and aligned, before being compared with various published strains and the homologies between the two Indian isolates were found both with one another and with other strains across the globe. The two Indian isolates used in the present study are known to vary between themselves as far as homologies related to other genes are concerned but they were found to be $100 \%$ homologous as far as SAG3 locus is concerned. This could be attributed to the fact that this SAG3 might be a conserved locus and therefore, further detailed studies are thereby warranted to exploit the use of this particular molecule in diagnostics and immunoprophylactics. The findings are important from the point of view of molecular phylogeny.

\section{RESUMO}

\section{Caracterização molecular e análise filogenética de sequências do antígeno de superfície 3 (SAG3) em isolados indianos (CHENNAI E IZATNAGAR) de Toxoplasma gondii}

Contexto e objetivo. A caracterização molecular de isolados indianos de Toxoplasma gondii é importante para a investigação de variações genéticas existentes entre cepas do parasito em diferentes locos gênicos. Delineamento e disposição. A presente comunicação realizou a clonagem e o sequenciamento dos 1158 pares de base correspondendo à totalidade do quadro de leitura do antígeno de superfície 3 (SAG3) de Toxoplasma gondii em dois isolados indianos (Chennai e Izatnagar) mantidos em um biorrepositório localizado em IVRI. Método. As sequências do SAG3 dos dois isolados indianos foram clonadas, sequenciadas e posteriormente comparadas com sequências SAG3 de Toxoplasma gondii disponíveis em publicações. Resultados. A comparação das sequências revelou 99,9\% de homologia com a cepa RH padrão; 99,3\% de homologia com as cepas P-Br e CEP; e 98,4\% de homologia com a cepa PRU. Os dois isolados indianos eram $100 \%$ idênticos no que diz respeito à sequência SAG3. Conclusão. Concluiu-se que os isolados indianos são filogeneticamente mais próximos da cepa $\mathrm{RH}$ em relação à cepa brasileira $\mathrm{P}-\mathrm{Br}$, ou às cepas CEP e PRU (USA). No entanto, a análise de outros genes de Toxoplasma gondii destes dois isolados indianos mostrou diferenças na composição de nucleotídeos, ao contrário do que foi encontrado para o locus SAG3. Estes resultados poderiam ser atribuídos ao fato do locus SAG3 ser altamente conservado, necessitando de estudos adicionais para determinar se SAG3 poderia ser utilizado no diagnóstico da toxoplasmose. No entanto, estes resultados são importantes do ponto de vista da filogenia molecular.

\section{ACKNOWLEDGMENTS}

The authors are thankful to the Director, IVRI for providing the facilities and to the ICAR for the fellowship awarded to the first author during the perusal of his master's programme. The authors declare that there is no conflict of interest.

\section{REFERENCES}

1. Alvarado-Esquivel C, Alanis-Quiñones OP, Arreola-Valenzuela MA, Rodríguez- Briones A, Piedra-Nevarez IJ, Duran-Morales E, et al. Seroepidemiology of Toxoplasma gondii infection in psychiatric inpatients in a northern Mexican city. BMC Infect Dis. 2006;6:178. 

of Toxoplasma gondii. Rev. Inst. Med. Trop. Sao Paulo, 57(3): 205-9, 2015.

2. Angel SO, Matrajt M, Margarit J, Nigro N, Illescas E, Pszenny V, et al. Screening of active Toxoplasma in patients by DNA hybridization with ABGTg7 probe in blood samples. J Clin Microbiol. 1997;35:591-5.

3. Ajzenberg D, Banuls AL, Su C, Dumetre A, Demar M, Carme B, et al. Genetic diversity, clonality and sexuality in Toxoplasma gondii. Int J Parasitol. 2004;34:1185-96.

4. Balasundaram MB, Andavar R, Palaniswamy M, Venkatapathy N. Outbreak of acquired ocular toxoplasmosis involving 248 patients. Arch Ophthalmol. 2010;128:28-32.

5. Beaman MH, Wong SY, Remington JS. Cytokines, Toxoplasma and intracellular parasitism. Immunol Rev. 1992;127:97-117.

6. Burg JL, Perelman D, Kasper IH, Ware PL, Boothroyd JC. Molecular analysis for gene encoding the major surface antigens of Toxoplasma gondii. J Immunol. $1988 ; 141: 3584-91$

7. Cesbron-Delauw MF, Tomavo S, Beauchamps P, Fourmaux MP, Camus D, Capron A, et al. Similarities between the primary structures of two distinct major surface protein of Toxoplasma gondii. J Biol Chem. 1994;269:16217-22

8. Daryani A, Sharif M, Hosseini SH, Karimi SA, Gholami S. Serological survey of Toxoplasma gondii in schizophrenia patients referred to psychiatric hospital, Sari city, Iran. Trop Biomed. 2010;27:476-86.

9. Dubey JP. Toxoplasmosis: a waterborne zoonosis. Vet Parasitol. 2004;126:57-72.

10. Dzierszinski F, Mortuaire M, Cesbron-Delauw MF, Tomavo S. Targeted disruption of the glycosylphosphatidylinositol-anchored surface antigen SAG3 gene in Toxoplasma gondii decreases host cell adhesion and drastically reduces virulence in mice. Mol Microbiol. 2000;37:574-82

11. Fekadu A, Shibre T, Cleare AJ. Toxoplasmosis as a cause for behavior disorders - overview of evidence and mechanisms. Folia Parasitol (Praha). 2010;57:105-13.

12. Ferguson DJ. Toxoplasma gondii and sex: essential or optional extra? Trends Parasitol. 2002; 18:355-89.

13. Fux B, Rodrigues CV, Portela RW, Silva NM, Su C, Sibley D, et al. Role of cytokines and major histocompatibility complex restriction in mouse resistance to infection with a natural recombinant strain (Type I-III) of Toxoplasma gondii. Infect Immun. 2003;71:6392-401

14. Grigg ME, Bonnefoy S, Hehl AB, Suzuki Y, Boothroyd JC. Success and virulence in Toxoplasma as the result of sexual recombination between two distinct ancestries. Science. 2001;294:161-5.

15. Gross U, Muller WA, Knapp S, Heesemann J. Identification of a virulence-associated antigen of Toxoplasma gondii by a mouse monoclonal antibody. Infect Immun. 1991;59:4511-6.

16. Hill D, Dubey JP. Toxoplasma gondii: transmission, diagnosis and prevention. Clin Microbiol Infect. 2002;8:634-40.

17. Howe DK, Sibley LD. Toxoplasma gondii comprises three clonal lineages: correlation of parasite genotype with human disease. J Infect Dis. 1993;172:1561-66.

18. Jacquet A, Coulon L, De Nève J, Daminet V, Haumont M, Garcia L, et al. The surface antigen SAG3 mediates the attachment of Toxoplasma gondii to cell-surface proteoglycans. Mol Biochem Parasitol. 2001;116:35-44.
19. Kazemi B, Maghen L, Bandehpour M, Shahabi S, Haghighi A. Gene cloning of P43 surface protein of Toxoplasma gondii tachyzoite and bradyzoite (SAG3). Gene Ther Mol Biol. 2007;11:113-6.

20. Khan A, Jordan C, Muccioli C, Vallochi AL, Rizzo LV, Belfort JR, et al. Genetic divergence of Toxoplasma gondii strains associated with ocular toxoplasmosis, Brazil. Emerg Infect Dis. 2006;12:942-9.

21. Lee YH, Shin DW, Lee JH, Nam HW, Ahn MH. Vaccination against murine toxoplasmosis using recombinant Toxoplasma gondii SAG3 antigen alone or in combination with Quil A. Yonsei Med J. 2007;48:396-404.

22. Montoya JG, Liesenfeld O. Toxoplasmosis. Lancet. 2004;363(9425):1965-76

23. Praveen K, Bansal GC, Vikram K, Zahid AK, Saravanan BC, Tewari AK, et al. Cloning and molecular characterization of microneme protein-3 (MIC3) gene of Izatnagar and Chennai isolates of Toxoplama gondii. J Vet Parasitol. 2012;26:31-4.

24. Sambrook J, Fritch EF, Maniatis T. Molecular cloning: a laboratory manual. $2^{\text {nd }}$ ed. New York: Cold Spring Harbor; 1989

25. Sreekumar C, Graham DH, Dahl E, Lehmann T, Raman M, Bhalerao DP, et al. Genotyping of Toxoplasma gondii isolates from chickens from India. Vet Parasitol. 2003;118(34):187-94.

26. Singh H, Tewari AK, Mishra AK, Maharana BR, Rao JR, Raina OK. Molecular cloning, comparative sequence analysis and prokaryotic expression of GRA5 protein of Toxoplasma gondii. Indian J Anim Sci. 2011a;81:209-15.

27. Singh H, Tewari AK, Mishra AK, Maharana BR, Rao JR, Raina OK. Molecular cloning and comparative sequence analysis of open reading frame of SAG2 gene of Toxoplasma gondii. J Vet Parasitol. 2011b;25:107-12.

28. Sudan V, Tewari AK, Singh H, Saravanan BC, Sankar M. Molecular characterization of surface antigen 3 (SAG3) gene of Toxoplasma gondii RH-IVRI strain. J Parasit Dis. 2012;36:210-14

29. Sudan V, Tewari AK, Singh H. An insight into the behavior, course and kinetics of acute infection of Toxoplasma gondii human RH strain in experimentally infected murine model. Iranian J Parasitol. 2014;9:114-9.

30. Su C, Evans D, Cole RH, Kissinger JC, Ajioka JW, Sibley LD. Recent expansion of Toxoplasma through enhanced oral transmission. Science. 2003;299(5605):414-6.

31. Tenter AM, Heckeroth AR, Weiss LM. Toxoplasma gondii: from animals to humans. Int J Parasit. 2000;30(12-13):1217-58.

32. Webster JP, Lamberton PHL, Donnelly CA, Torrey EF. Parasites as causative agents of human affective disorders? The impact of anti-psychotic, mood- stabilizer and antiparasite medication on Toxoplasma gondii's ability to alter host behavior. Proc Biol Soc. 2006;273(1589):1023-30.

Received: 8 April 2014

Accepted: 8 August 2014 